\title{
Functional consequences and population differences in the developmental plasticity of muscle to temperature in Atlantic herring Clupea harengus
}

\author{
I. A. Johnston*, V. L. A. Vieira, G. K. Temple \\ Gatty Marine Laboratory, Division of Environmental \& Evolutionary Biology, School of Biology, University of St Andrews, \\ St Andrews, Fife KY16 8LB, Scotland, UK
}

\begin{abstract}
The development of the axial muscles was investigated in Atlantic herring Clupea harengus from 2 spring-spawning (Clyde and Blackwater) and 1 autumn-spawning (Manx) populations in 2 successive years. The results indicate significant developmental differences between stocks. Myofibril synthesis and the development of acetylcholinesterase activity at the neuromuscular junctions occurred later with respect to embryonic stage at $5^{\circ} \mathrm{C}$ than at 8 and $12^{\circ} \mathrm{C}$ in $\mathrm{Clyde}$ herring, with much less pronounced differences between temperatures for the other populations. In a second series of experiments, Clyde herring were incubated at 5 and $12^{\circ} \mathrm{C}$ until shortly after hatching, and then reared at ambient temperature in triplicate tanks. The $5^{\circ} \mathrm{C}$ group had a faster growth rate than the $12^{\circ} \mathrm{C}$ group with respect to effective day-degrees from hatch. However, flexion of the notochord and the development of the dorsal and anal fin ray muscles occurred at shorter body lengths in the 12 than $5^{\circ} \mathrm{C}$ groups. The maximum escape velocity of larvae during fast-starts was determined using a high-speed video. Over the size range 11.2 to $18.5 \mathrm{~mm}$ total length, the adjusted mean maximum velocity was $24 \%$ higher in larvae hatched from 12 than $5^{\circ} \mathrm{C}$ eggs. Cruising swimming behaviour also differed between groups with the $12^{\circ} \mathrm{C}$ larvae showing reduced yaw relative to the $5^{\circ} \mathrm{C}$ larvae, indicating a more developmentally advanced sub-carangiform style of locomotion.
\end{abstract}

KEY WORDS: Atlantic herring $\cdot$ Clupea harengus $\cdot$ Skeletal muscle $\cdot$ Temperature $\cdot$ Development · Growth $\cdot$ Swimming performance $\cdot$ Fast-starts

Resale or republication not permitted without written consent of the publisher

\section{INTRODUCTION}

Populations of Atlantic herring Clupea harengus L. from the North Sea, Baltic, Norwegian Sea and Iceland spawn in almost every month of the year over a wide range of sea temperatures (Parrish \& Saville 1967). Atlantic herring show a high homing fidelity to their spawning grounds (Wheeler \& Winters 1984), although there is evidence that spring spawning herring may turn into autumn spawners and vice versa (Anokhina 1971) indicating at least some gene flow between populations. Indeed, genetic studies using allozymes and

${ }^{*}$ E-mail: iaj@st-and.ac.uk mitochondrial markers indicate relatively little structuring between stocks (Jørstad \& Næevdal 1981, Grant 1984, Ryman et al. 1984), with the exception of isolated deep-water resident populations in Norwegian fjords (Jørstad et al. 1994, Turan et al. 1998). For example, Dahle \& Erikson (1990), using restriction fragment length polymorphism (RFLP) analysis, found no genetic differentiation between autumn and spring spawning populations of herring in the North and Baltic Seas. In contrast, a rich diversity of stocks can be identified on the basis of place and time of spawning and meristic characters including the numbers of vertebrae, fin rays, keeled scales, gill rakers and otolith fine structure (Parrish \& Saville 1967, Rosenberg \& Palmén 1982). 
The number of white muscle fibres per myotomal crosssection also shows significant differences between different spawning stocks that are consistent over several years (Greer-Walker et al. 1972). This lack of correspondence between the patterns of genetic and morphological variability (Ryman et al. 1984) can partly be explained by phenotypic plasticity during early development. Myotome and fin ray numbers have been shown to be particularly sensitive to temperature and salinity during the embryo stages (Hempel \& Blaxter 1961). It is also possible that the differences in muscle fibre number between herring populations have a developmental explanation. The number of white muscle fibres per myotome increases from a few hundred in yolk-sac larvae to tens of thousands in sexually mature individuals (Greer-Walker et al. 1972, Vieira \& Johnston 1992). The nuclei for fibre recruitment are thought to be derived from a population of undifferentiated myogenic cells called satellite cells (Koumans \& Akster 1995, Johnston 1999). For Clyde herring, the density of presumptive muscle satellite cells (Johnston 1993) and subsequent patterns of muscle growth were shown to be a function of egg incubation temperature (Johnston et al. 1998).

The temperature regime during embryonic development can have temporary as well as long-lasting effects on larval phenotype (Johnston et al. 1996). Muscle pioneer cells are the first fibres to develop myofibrils and become innervated in the trunk (Halpern et al. 1993). In Clyde herring, the relative timing of muscle and neural development during the embryo and early larval phases has been shown to be a function of temperature (Johnston et al. 1995, 1997, 1998). For example, embryonic isoforms of the myofibrillar proteins, myosin light chain 2, troponin I and troponin $\mathrm{T}$ were replaced by adult isoforms at longer body lengths at 5 than $12^{\circ} \mathrm{C}$ (Johnston et al. 1997). The development of acetylcholinesterase activity at the nerve terminals of the trunk muscles was shown to start in 31-somite stage embryos at $12^{\circ} \mathrm{C}$, but not until approximately the 40 -somite stage at $5^{\circ} \mathrm{C}$ (Johnston et al. 1997). In the larvae, a single superficial layer of slow muscle fibres surrounds an inner core of fast muscle fibres (Batty 1984, Vieira \& Johnston 1992). Initially, neuromuscular junctions were only present at the myoseptal ends of slow muscle fibres. The appearance of the adult pattern of multiple terminal innervation to slow muscle occurred in larvae of 12 to $14 \mathrm{~mm}$ at $12^{\circ} \mathrm{C}$, but not until 16 to $19 \mathrm{~mm}$ length at $5^{\circ} \mathrm{C}$ (Johnston et al. 1997). These results show that temperature variation during the early stages of ontogeny can uncouple growth and differentiation. In Clyde herring, such transient effects of temperature on development have largely disappeared in larvae greater than $22 \mathrm{~mm}$ total length (TL) (Johnston et al. 1998).
The present study was designed to test 2 hypotheses. First, that developmental responses to temperature are similar in spring spawning (Clyde and Blackwater) and autumn spawning (Manx) populations, reflecting the lack of genetic structuring between stocks. To test the hypothesis, eggs from each population were incubated at the same constant temperatures $(5,8$ and $12^{\circ} \mathrm{C}$ ), which included the natural range for each stock. In the Firth of Clyde, Clyde herring spawn in March at 10 to $20 \mathrm{~m}$ depth, experiencing average temperatures ranging from 4.8 to $10^{\circ} \mathrm{C}$ depending on natural climate variability (Jones \& Jeff 1991). Herring enter the Blackwater estuary to spawn in shallow water (2 to $10 \mathrm{~m}$ ) over an extended period from mid-February to late April during which time the mean sea temperatures warm from 6 to $10^{\circ} \mathrm{C}$. Embryos from this stock experience periods of reduced salinity and a pronounced tidal cycling of around $2^{\circ} \mathrm{C}$ (Temple et al. 2000). The Manx stock spawn at $30 \mathrm{~m}$ on the Douglas Bank in late September/early October when sea temperatures in the Irish Sea approach their seasonal maximum of 10 to $14^{\circ} \mathrm{C}$ (Bowers 1969, A Geffen pers. comm.).

The second hypothesis tested was that changes in the relative timing of neuromuscular development at different temperatures in Clyde herring would have significant functional consequences in terms of performance and swimming style during the early larval stages. Performance was assessed by examining maximum velocity during fast-starts whilst swimming style was investigated by measuring the yaw of the head during steady swimming. As herring larvae increase in length they alter their swimming style to suit the hydrodynamic regime (Batty 1984, Blaxter 1988). Prior to the development of median fins, an anguilliform style of locomotion is used in which large amplitude body movements occur over most of the body (Batty 1984). In larvae greater than $22 \mathrm{~mm} \mathrm{TL}$, a sub-carangiform style of swimming is adopted in which the amplitude of body movements increases markedly towards the tail (Batty 1984).

\section{MATERIALS AND METHODS}

Production of embryos. Mature Atlantic herring Clupea harengus were caught by trawling. Spawning stocks from the Firth of Clyde on the west coast of Scotland and the Blackwater Estuary on the east coast of England were sampled during March. The autumn spawning Isle of Man (Manx) population was sampled on the Douglas Bank, Irish Sea, during late September. All 3 populations were sampled in 1997 and in 1998. The dissected gonads were returned on ice to the Dunstaffnage Marine Laboratory (Clyde source population) or the Gatty Marine Laboratory (Blackwater and Manx source populations). The eggs from 6 fe- 
males per source population were fertilised on individually labelled microscope slides using the milt from 6 males to create 6 families in each year. A second batch of eggs was fertilised $12 \mathrm{~h}$ later so that all stages of embryonic development could be studied conveniently during the working day. The slides of fertilised eggs were incubated in slide holders in black-walled tanks at constant temperatures of 5,8 and $12^{\circ} \mathrm{C}\left(0.5^{\circ} \mathrm{C}\right.$ range) (10 h light:14 h dark) as described in Johnston et al. (1997). Samples of 20 eggs per family were dried at $60^{\circ} \mathrm{C}$ for $24 \mathrm{~h}$ and individually weighed to determine the average egg dry mass per family.

Larval rearing. Mature Atlantic herring were caught in the Firth of Clyde during March 1998. The dissected gonads were returned on ice to the Dunstaffnage Marine Laboratory. The eggs from more than 20 females were fertilised with the milt from approximately 10 males as previously described (Johnston 1993). The fertilised eggs were incubated on large glass plates in triplicate $500 \mathrm{l}$ black-walled tanks at constant temperatures of 5 and $12^{\circ} \mathrm{C}\left(0.5^{\circ} \mathrm{C}\right.$ range) $(10 \mathrm{~h}$ light: $14 \mathrm{~h}$ dark). Fish were fed to excess with rotifers for the first few days after hatching and subsequently fed ad libitum with live Artemia sp. enriched with SuperSelco ${ }^{\mathrm{TM}}$ (INVE, Gent, Belgium). Prey densities were approximately $1000 \mathrm{l}^{-1}$. Once the fish began to feed, the temperature was switched to that of the ambient seawater supply (Fig. 1). The larvae were sampled from each tank at intervals and their standard length (SL) and total length (TL) measured. To obtain a measure of growth that was independent of temperature the number of effective day-degrees ( $\left.D^{\circ}{ }_{\text {eff }}\right)$ was calculated (Weltzien et al. 1999). $D^{\circ}$ eff was calculated as follows:

$$
D^{\circ}{ }_{\text {eff }}=\Delta t\left(T-T_{\mathrm{o}}\right)
$$

where $\Delta t$ is the growth period in days, $T$ is the temperature in ${ }^{\circ} \mathrm{C}$ and $T_{\mathrm{o}}$ is the threshold temperature at which development is theoretically arrested (obtained from the relationship between temperature and 1/time to $50 \%$ hatch of the embryos) (Weltzien et al. 1999).

Observations of living embryos. The formation of myofibrils within the muscle fibres was investigated in live embryos using Differential Interference Contrast (DIC) (Nomarski) microscopy. Slides were removed at intervals and examined in petri dishes before being returned to the rearing tanks. Frequent changes of seawater, maintained at the temperature of the rearing tank, were made to avoid heating during observations. After the 30-somite stage, some of the eggs were scraped from the slide with a razor blade and the embryos removed from the egg capsule using fine forceps. The embryos were killed with an overdose of bicarbonate-buffered tricaine methanesulphonate (MS222) and mounted in glycerol under glass coverslips supported by silicone grease at each corner. Each

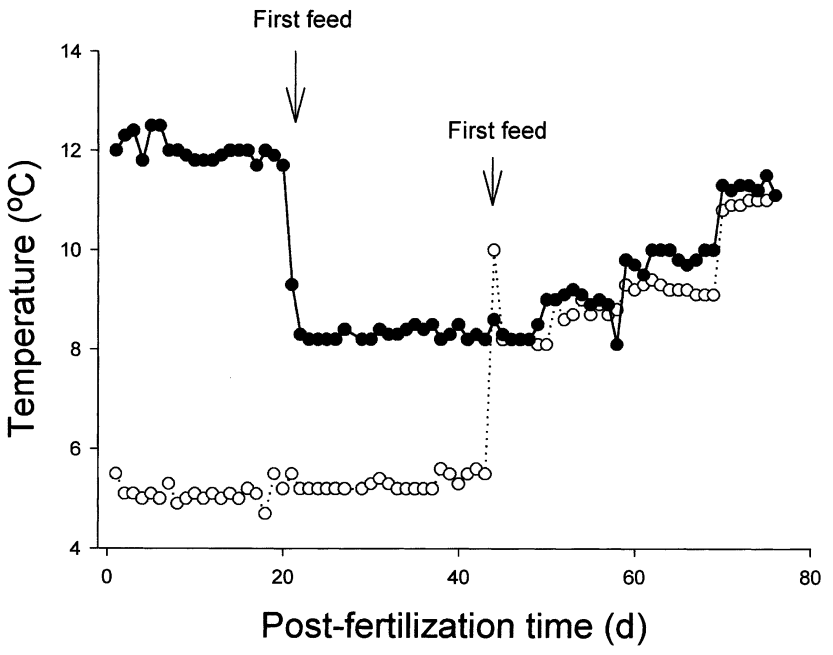

Fig. 1. Clupea harengus. Experimental design for the larval rearing experiments with Atlantic herring. Embryos were incubated at either around $5(0)$ or $12^{\circ} \mathrm{C}(\bullet)$ until first feeding and then reared at ambient temperature

sample contained a selection of the different families. The position of the most posterior somite containing myotubes and myofibrils were noted along with the somite stage of the embryo at a magnification of $\times 400$ using a Leitz DMRB system microscope. Myofibrils were identified by the presence of cross-striations. Although somite stage provides a reliable method of assessing the degree of development of herring embryos (Hill \& Johnston 1997a), it cannot be used after the completion of segmentation. Embryos were therefore staged with respect to the number of somite intervals (si) from the development of the first somite (Hill \& Johnston 1997b). The somite interval, the time required to add 1 somite pair, was calculated from plots of somite stage versus age post-fertilisation. The first $62 \mathrm{si}$ are equivalent to the somite stage of the embryo.

Acetylcholinesterase staining. Embryos and larvae were killed with an overdose of bicarbonate-buffered MS222 and washed in phosphate-buffered saline (PBS). Samples were fixed for 6 to $12 \mathrm{~h}$ in $4 \%(\mathrm{~m} / \mathrm{v})$ paraformaldehyde in $0.12 \mathrm{mmol} \mathrm{l}^{-1}$ phosphate buffer, pH 7.2 at $4^{\circ} \mathrm{C}$. The samples were washed in phosphate buffer and made permeable by incubation for $2 \mathrm{~h}$ in $1 \%$ saponin $(\mathrm{m} / \mathrm{v})$ in $0.12 \mathrm{mmol} \mathrm{l}^{-1}$ phosphate buffer, pH 7.2 at $4^{\circ} \mathrm{C}$. After exhaustive washing in phosphate buffer, fish were stained for acetylcholinesterase (AchE) activity by the method of Karnovsky \& Roots (1964) as previously described (Johnston et al. 1997). The staining reaction was stopped by rinsing specimens in PBS. Samples were mounted under glass coverslips in glycerol and photographed using a Leitz DMRB system microscope fitted with Nomaski optics and a polarising filter. 
Swimming experiments. Larvae were filmed between 34 and $63 \mathrm{~d}$ post hatch when TL ranged from 11.2 to $18.5 \mathrm{~mm}$. Filming was carried out in an airconditioned room where the temperature was set to that of ambient seawater. During the period of filming, the seawater temperature increased from 8.4 to $9.5^{\circ} \mathrm{C}$. However, larvae of a given length were filmed at the same temperature in both groups. Larvae were placed in a $190 \times 190 \times 50 \mathrm{~mm}$ (length $\times$ width $\times$ depth) tank and left to settle for $30 \mathrm{~min}$ prior to filming. Fast-starts were elicited by introducing a pipette tip into the arena. Larvae were filmed from directly above the swim tank using a high speed video (HSV-400, NAC Inc., Japan) at a frame rate of $200 \mathrm{~s}^{-1}$. Illumination was provided by a stroboscopic lamp, which was synchronised with the video system and reflected by a halfsilvered mirror onto the Scotchlite base of the swim tank to provide silhouettes of the larvae.

Steady swimming behaviour was also investigated using a standard video recorder set directly above the rearing tanks. Illumination was provided by a submerged infrared light. Filming was carried out at $8.4^{\circ} \mathrm{C}$ when the average TLs of the larvae were $12.8 \pm 0.3 \mathrm{~mm}$ $(\mathrm{n}=21)$ for the $12^{\circ} \mathrm{C}$ group and $12.8 \pm 0.2 \mathrm{~mm}(\mathrm{n}=11)$ for the $5^{\circ} \mathrm{C}$ group $( \pm \mathrm{SEM})$.

Kinematic analysis was carried out using Mathematica version 4.0 (Wolfram Research Europe Ltd, UK) and following the principles of Wakeling \& Johnston (1998) whereby velocity was determined from the displacement of the centre of mass of the fish. Prior to analysing the sequences, it was necessary to establish the mass distribution along the fish. The method used assumes the fish to have an elliptical profile in cross section and the volume distribution to approximate the mass distribution. Following an escape response, individual larvae were transferred to a petri dish containing seawater where longitudinal and planiform images were captured with a standard video and TL recorded. The coordinates around the outline of each image were obtained using NIH Image version 1.52 (NIH, USA). The masses of 10 equally spaced segments were calculated from the width, depth and longitudinal dimensions of each segment and expressed as non-dimensional mass. Forty escape response sequences were digitised via a Win/TV image grabber card (Hauppauge, UK). Ten points were digitised from snout to tail tip down the centre of each larva. The position of the spine was calculated from these points using a cubic spline function. The centre of mass was calculated for each frame using the positions of the centres of the 10 equally spaced segments along the spine and their masses. Lengthspecific velocity was calculated from the displacement of the centre of mass. The $x$ and $y$ position data were smoothed using piecewise cubic regressions and ab- solute maximum velocity $\left(U_{\max } \mathrm{mm}^{-1}\right)$ was recorded for each escape response.

The yaw of the head during steady swimming behaviour was determined in 17 larvae. The yaw was calculated as the total angle the head turned from one side to the other over a tail beat. The $x$ and $y$ coordinates of the tip of the snout and a point just posterior to the head were digitised as described above over a minimum of 5 changes in snout direction.

Statistical analysis. Embryonic development: Multiple regression analysis was used to investigate the degree of association between the explanatory variables and the response variable (Weisberg 1985). Factors amongst the explanatory variables were: population source $($ рор) $)(1=$ Clyde, $2=$ Blackwater and $3=$ Manx), rearing temperature (temp) $\left(1=5^{\circ} \mathrm{C}, 2=8^{\circ} \mathrm{C}\right.$ and $\left.3=12^{\circ} \mathrm{C}\right)$ and year $(1=1997,2=1998)$. The covariates investigated were egg dry mass (egg) and the somite-interval (si) of the embryos. Response variables, the number of somites containing myofibrils and AchE staining at the myosepta, were modelled separately. Different model selection techniques were used with and without suspected outliers being included. Results, as far as the final model selected, were consistent between the different selection techniques that did or did not include suspected outliers. The statistical modelling results reported were based on backward elimination (Krzanowski 1998). The elimination of a main effect of a factor or covariate was not considered until all interactions involving the factor of interest were eliminated. The selection criteria were based on the $C_{p}$ statistic. This statistic provides a convenient criterion for determining whether a model is improved by dropping a term. If any term had a $C_{p}$ statistic lower than that of the current model, the term with the lowest $C_{p}$ statistic was dropped. If the current model had the lowest $C_{p}$ statistic, then the model was not improved by dropping any term. The interactions considered in model selection were: $p o p \times$ temp, pop $\times$ year, temp $\times$ year, temp $\times$ pop $\times$ year, egg $\times$ pop, egg $\times$ year. The following dummy variables were created for each population: (1) pop $1=1$ if from Clyde and pop $1=0$ if from Blackwater or Manx, (2) pop $2=1$ if from Blackwater and pop $2=0$ if from Clyde or Manx, (3) pop $3=$ 1 if from Manx and pop $3=0$ if from Blackwater or Clyde.

After the final model was selected, 3 models were fitted: (1) Blackwater and Manx were pooled into 1 population and Clyde was kept separate; this was done by substituting the variable pop 1 for pop in the final model $_{i}$ (2) Clyde and Manx were pooled into 1 population and Blackwater was kept separate, this was done by substituting the variable pop 2 for pop in the final model; and (3) Blackwater and Clyde were pooled into 1 population and Manx kept separate; this was done 
by substituting the variable pop 3 for pop in the final model. If the $F$-statistic was not significant for a population grouping, then there was evidence that the 2 populations could be pooled. If the $F$-statistic, derived when population $i$ was grouped with one of the other 2 populations, was higher than for population $i$ alone, then there was evidence that population $i$ had a stronger association with the difference in the response variable than the other 2 populations.

Larval development: Analysis of covariance (ANCOVA) was used to compare the effects of different egg incubation temperatures on the subsequent development of the innervation to the fin ray muscles with larval total body length as a covariate.

Swimming experiments: Linear regressions $\left(a \mathrm{TL}^{b}\right)$ were calculated on log transformed data using least squares regression analysis. The significance of all regression lines was assessed using the ANOVA $F$ statistic. The effect of initial rearing temperature on the slopes and elevations of $U_{\max }$ was tested with an ANCOVA (Zar 1996). Maximum angles of yaw were compared between groups using a 1-way ANOVA. Tests were considered significant at the $95 \%$ confidence level.

\section{RESULTS}

\section{Egg dry mass}

The average and range of values (in brackets) of egg dry mass (mg) in the herring families studied were as follows: Clyde 1997: $0.32 \pm 0.0049(0.32-0.33)$; Clyde 1998: $0.31 \pm 0.065$ (0.25-0.43); Blackwater 1997: $0.32 \pm 0.024(0.28-0.35)$; Blackwater 1998: $0.31 \pm 0.19$ (0.29-0.34); Manx 1997: $0.30 \pm 0.017$ (0.28-0.32); Manx 1998: $0.42 \pm 0.066(0.32-0.51)($ Mean $\pm S D$, $\mathrm{n}=6$ ). There were no systematic differences in mean egg size between the families selected from the different populations studied.

\section{Egg incubation temperature and myogenesis}

Somites were formed in a rostral to caudal direction starting at the early neural plate stage. The somite stage of the embryo was plotted against time postfertilisation to calculate the time required to form 1 somite pair (data not illustrated). The rate of somite formation varied from 1 pair every 2.6 to $4.2 \mathrm{~h}$ at $5^{\circ} \mathrm{C}$ to 1 pair every 0.9 to $1.5 \mathrm{~h}$ at $12^{\circ} \mathrm{C}$, with no consistent differences between years and/or populations. The synthesis of myofibrils showed a rostral to caudal progression, starting in the mononuclear muscle pioneer fibres at the level of the major horizontal septum and progressing to the adjacent multi-nucleated myotubes (Fig. 2B). The development of myofibrils in the most caudal somites did not occur until after all the somites had been formed and therefore embryos were staged using the number of somite intervals (see 'Materials and methods'). AchE staining was first observed in the cell bodies of primary motor neurones (Fig. 2A). There were 3 primary motor neurones per somite (Fig. 2A). Typically, 8 to 13 cell bodies were stained before any AchE activity was detected at the myosepta (Fig. 2A). Since comparatively few embryos were found with fewer numbers of somites stained, it is likely that AchE activity at the neuromuscular junctions developed almost simultaneously in the first 8 to 13 somites. Subsequently, there was a rostral to caudal progression of AchE staining at the myosepta, which gradually intensified as embryogenesis progressed (Fig. 2C).

The relationship between the most posterior somite with myofibrils and somite-interval for the different incubation temperatures and source populations is shown in Fig. 3, and the corresponding regression equations are given in Table 1. A convenient way to display the results is to calculate the somite interval at which the first 20 somites contained myofibrils (Fig. 4). For the Clyde population at $5^{\circ} \mathrm{C}, 20$ myotubes contained myofibrils in 50-somite stage embryos in 1997 and in 44-somite stage embryos in 1998 (Fig. 4). Myofibril synthesis occurred earlier with respect to somite interval at 8 and $12^{\circ} \mathrm{C}$ (Figs. $3 \& 4$ ). On average in Clyde herring, 20 myotubes had developed myofibrils by the 39 to 41 somite stages at 8 and $12^{\circ} \mathrm{C}$ in both years (Fig. 4). For the Blackwater and Manx source populations, there was more consistency in results between years, with a similar though much less pronounced trend for myofibril formation to occur at later somite stages at 5 rather than $12^{\circ} \mathrm{C}$ (Fig. 4). Multiple regression analysis and backward elimination model selection resulted in the dropping of the explanatory variables of $p o p \times$ year, $p o p \times$ year $\times$ temp, egg $\times$ pop and egg $\times$ year. The significance levels in the final model selected are shown in Table 2. Significance levels were calculated using the F-statistic when variable and all higher order interactions involving that variable were dropped from that model. The factors of pop, temp and year and the covariate of egg were all significant (Table 2). There were also significant $p o p \times$ temp and year $\times$ temp interaction terms (Table 2). The results for grouping the populations for the response variable myofibrils are shown in Table 3. The lowest F-statistic was obtained when the Blackwater and Manx populations were pooled and treated as if coming from 1 population and the Clyde was treated as a separate population (Table 3). Since the F-statistics for each popula- 


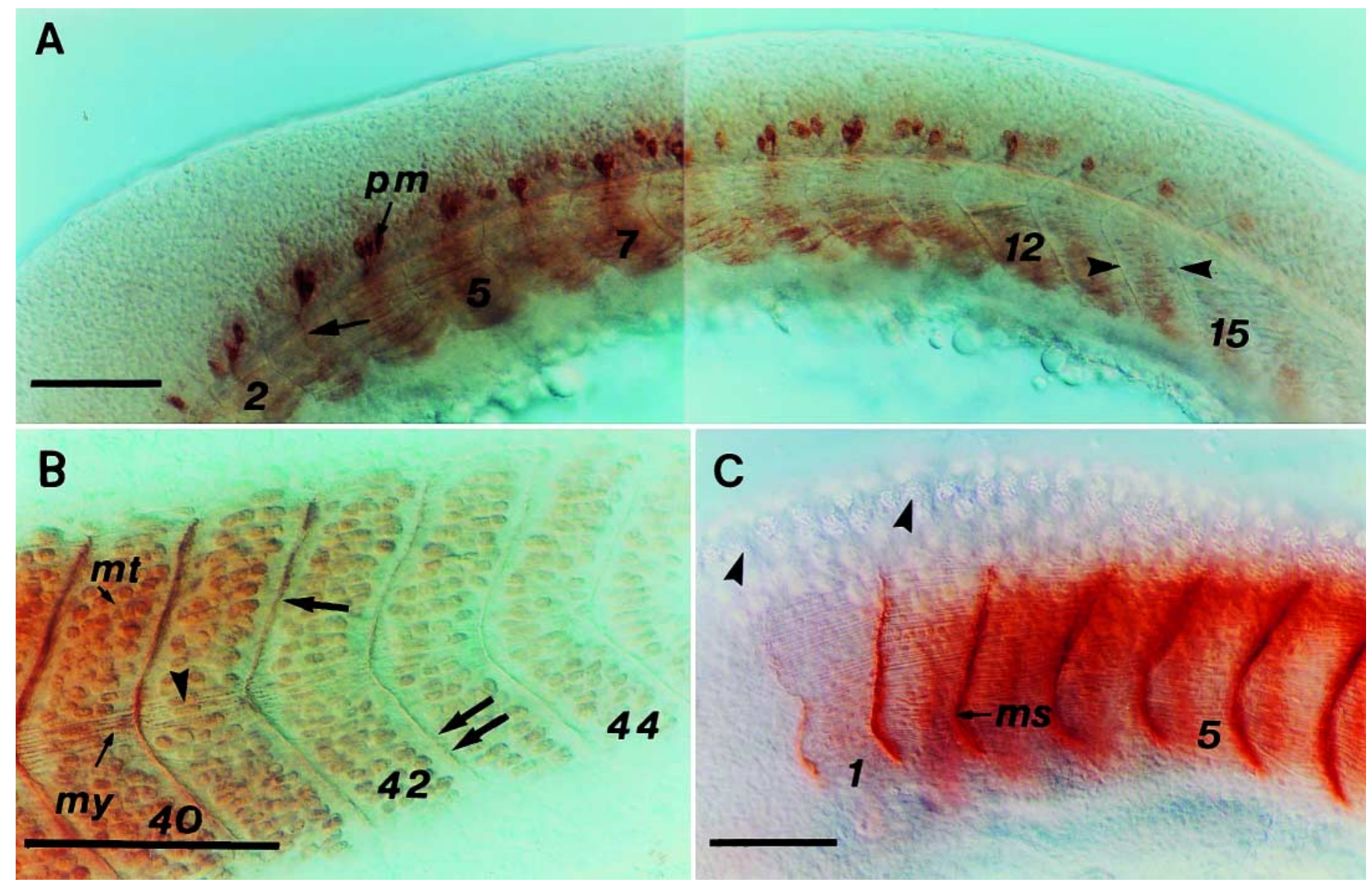

Fig. 2. Clupea harengus. Development of AchE staining in the trunk of Atlantic herring embryos from the Clyde population reared at $12^{\circ} \mathrm{C}$. The numbers indicate the somite number counting from the head. (A) A 31-somite stage embryo. The arrow indicates AchE staining in a primary motor neurone and the inward facing arrowheads illustrate the limits of a somite. pm: primary motor neurone cell body. (B) A 55-somite stage embryo. The arrowhead illustrates a mononuclear muscle pioneer fibre containing myofibrils. The arrow indicates the limit of the myosepta stained for AchE activity and the double arrow an unstained myosepta. (C) The first 7 somites of a 58-somite stage embryo showing intense AchE staining at the myosepta (ms). Arrowhead illustrates hatching glands developing in the head region. Other abbreviations: mt: multi-nucleated myotube; my: myofibrils.

Scale bars $=100 \mu \mathrm{m}$

tion grouping were significant none could be pooled. The results indicate that Clyde herring accounted for the greatest amount of difference between populations, but that they were all significantly different from each other.

The relationship between the number of somites with AchE staining at the myosepta and somite interval is shown in Fig. 5 and Table 4. In the Clyde population, the development of AchE staining at the myosepta was markedly delayed with respect to somite stage at $5^{\circ} \mathrm{C}$ compared to 8 or $12^{\circ} \mathrm{C}$ (Fig. 6). For example, 20 somites had AchE staining at the myo-septa at the 39 -somite stage at $8^{\circ} \mathrm{C}$, compared with the 45 to 48 -somite stage at $5^{\circ} \mathrm{C}$ (Fig. 6). In contrast, the development of AchE staining at the myosepta was relatively independent of temperature for embryos from the Blackwater and Manx source populations (Fig. 6). The levels of significance in the final multiple regression model selected are shown in Table 5 . The egg $\times$ year explanatory variable was dropped from the final model. Egg, pop, temp and year were all significant factors in the final model, with a number of significant interaction terms (Table 5). The results for grouping the populations are shown in Table 6. Once again, the lowest F-statistic was obtained when the Blackwater and Manx populations were pooled and treated as if coming from 1 population and Clyde was treated as a separate population (Table 6). Clyde herring therefore accounted for the greatest amount of difference between the populations although all were significantly different from each other. 
Fig. 3. Clupea harengus. Myofibril formation at different temperatures in embryos of Atlantic herring. The relationship between the most posterior somite with myofibrils and the somite interval of the embryo is illustrated for the Clyde (•), Blackwater (0) and Manx ( $\mathbf{\Delta}$ ) spawning populations in 1997 and 1998. Each point represents a measurement from an individual embryo. First order linear regressions were fitted to the data
A) $12^{\circ} \mathrm{C}$
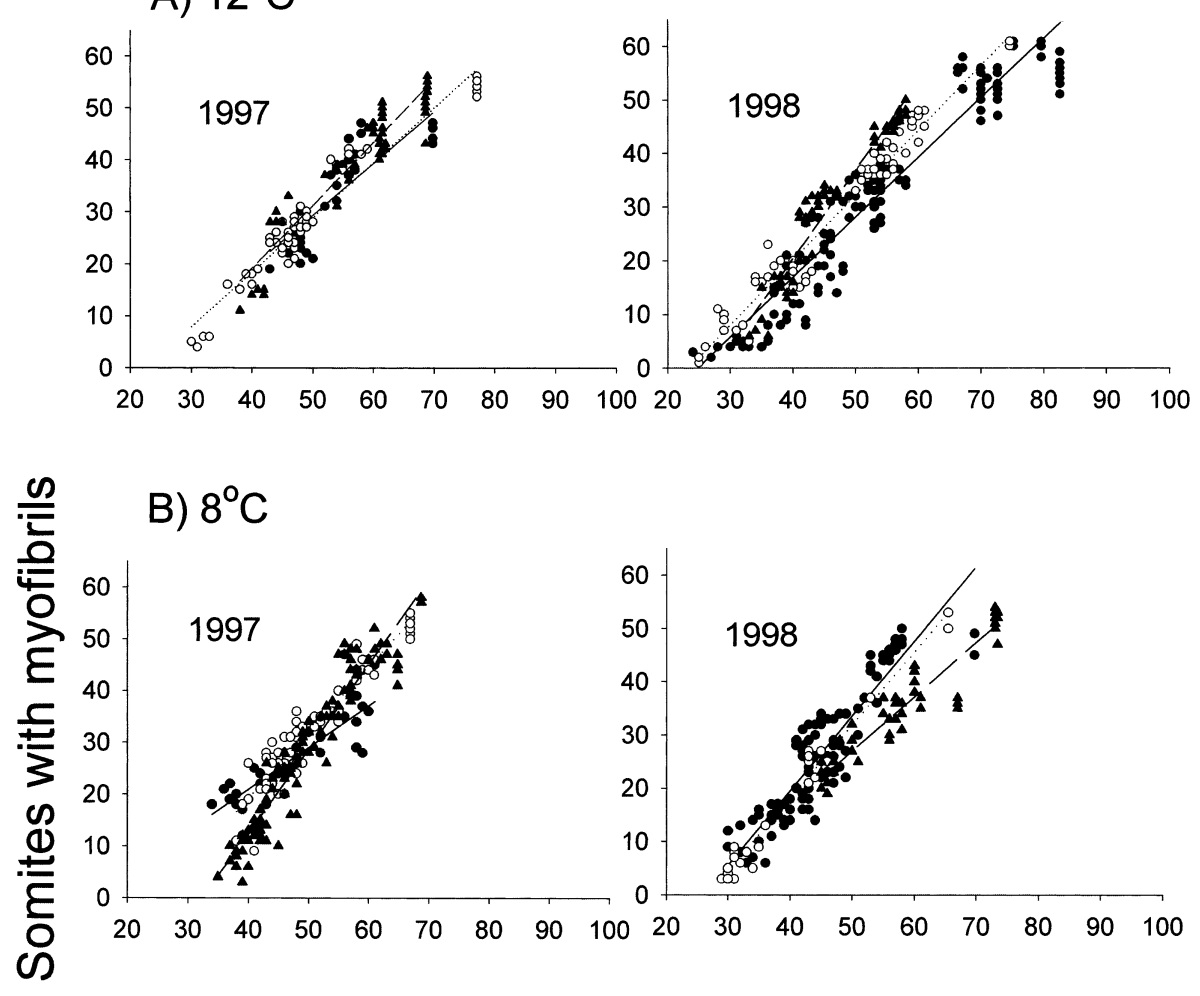

C) $5^{\circ} \mathrm{C}$

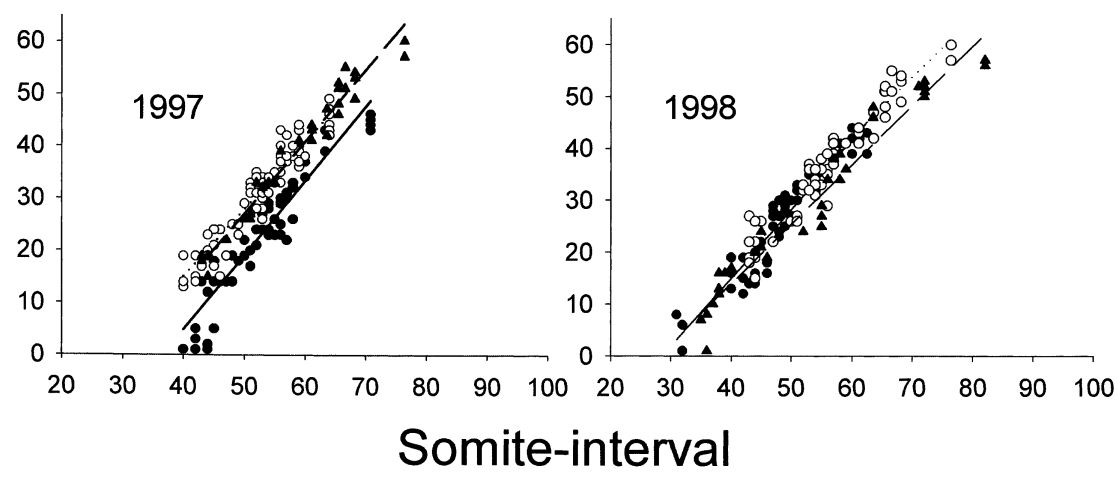

\section{Consequences of egg incubation temperatures for larval development}

The relationship between the rate of embryonic development $(V)$ in Clyde herring and temperature is shown in Fig. $7 \mathrm{~A}$, where $V=1 /$ time to $50 \%$ hatch in days. The data were taken from the present study and the literature. The extrapolated temperature at which $V$ was equal to 0 was $1.1^{\circ} \mathrm{C}$ (calculated from the linear regression equation in Fig. 7A).

Fish were incubated at nominal temperatures of 5 and $12{ }^{\circ} \mathrm{C}$ until first feeding and then transferred to ambient temperature (Fig. 1). In an attempt to provide a measure of development normalised for differences in temperature post-first feeding the effective day degrees $\left(D^{\circ}{ }_{\text {eff }}\right)$ for each group was calculated. The relationship between larval standard length and $D^{\circ}$ eff for the $5^{\circ} \mathrm{C}(\circ)$ and $12^{\circ} \mathrm{C}(\bullet)$ groups is shown in Fig. $7 \mathrm{~B}$. ANCOVA with $D^{\circ}$ eff as covariate $\left(F_{1,287}=727.7 ; \mathrm{p}<\right.$ $0.0001)$ revealed a significant main effect of egg incubation temperature on standard length $\left(F_{1,287}=87.23\right.$; $\mathrm{p}<0.0001)$. The specific growth rate $\left(G_{0}\right)$ in standard length of the 2 groups was calculated according to the formula:

$$
G_{\mathrm{o}}=100\left(\ln \mathrm{SL}_{t}-\ln \mathrm{SL}_{\mathrm{o}}\right) \cdot D_{\text {eff }}^{\circ-1}
$$

where SL is the standard length $(\mathrm{mm})$ of the larvae at time $t$ (days), $\mathrm{SL}_{\mathrm{o}}$ is the $\mathrm{SL}$ of the larvae at transfer to 
Table 1. Clupea harengus. Relationship between the most posterior somite with myofibrils and somite interval for embryos of Atlantic herring from different populations. The data were fitted by least squares regression to an equation of the form: number of somites containing myofibrils $=a+b$ (somite interval). Values represent mean $\pm \mathrm{SD}$

\begin{tabular}{|c|c|c|c|c|c|}
\hline $\begin{array}{l}\text { Temperature } \\
\left({ }^{\circ} \mathrm{C}\right) / \text { Year }\end{array}$ & $\begin{array}{c}\text { Intercept } \\
a\end{array}$ & $\begin{array}{l}\text { Slope } \\
\quad b\end{array}$ & df & $\begin{array}{c}\mathrm{r}^{2-} \\
\text { adjusted }\end{array}$ & $\mathrm{p}$-value \\
\hline \multicolumn{6}{|l|}{$12^{\circ} \mathrm{C}$} \\
\hline \multicolumn{6}{|l|}{ Clyde } \\
\hline 1997 & $-20.45 \pm 4.81$ & $0.99 \pm 0.088$ & 41 & 0.75 & $<0.0001$ \\
\hline 1998 & $-27.69 \pm 1.58$ & $1.12 \pm 0.028$ & 148 & 0.91 & $<0.0001$ \\
\hline \multicolumn{6}{|l|}{ Blackwater } \\
\hline 1997 & $-23.56 \pm 1.94$ & $1.05 \pm 0.039$ & 52 & 0.93 & $<0.0001$ \\
\hline 1998 & $-28.26 \pm 1.48$ & $1.21 \pm 0.030$ & 60 & 0.96 & $<0.0001$ \\
\hline \multicolumn{6}{|l|}{ Manx } \\
\hline 1997 & $-29.15 \pm 3.28$ & $1.21 \pm 0.053$ & 64 & 0.89 & $<0.0001$ \\
\hline 1998 & $-45.36 \pm 2.73$ & $1.64 \pm 0.059$ & 56 & 0.93 & $<0.0001$ \\
\hline \multicolumn{6}{|l|}{$8^{\circ} \mathrm{C}$} \\
\hline \multicolumn{6}{|l|}{ Clyde } \\
\hline 1997 & $-11.50 \pm 3.25$ & $0.81 \pm 0.068$ & 33 & 0.80 & $<0.0001$ \\
\hline 1998 & $-36.51 \pm 2.55$ & $1.40 \pm 0.056$ & 106 & 0.85 & $<0.0001$ \\
\hline \multicolumn{6}{|l|}{ Blackwater } \\
\hline 1997 & $-31.64 \pm 2.52$ & $1.27 \pm 0.048$ & 74 & 0.90 & $<0.0001$ \\
\hline 1998 & $-36.58 \pm 1.65$ & $1.37 \pm 0.040$ & 24 & 0.98 & $<0.0001$ \\
\hline \multicolumn{6}{|l|}{ Manx } \\
\hline 1997 & $-53.13 \pm 2.62$ & $1.64 \pm 0.051$ & 100 & 0.91 & $<0.001$ \\
\hline 1998 & $-24.02 \pm 2.98$ & $1.02 \pm 0.049$ & 48 & 0.90 & $<0.0001$ \\
\hline \multicolumn{6}{|l|}{$5^{\circ} \mathrm{C}$} \\
\hline \multicolumn{6}{|l|}{ Clyde } \\
\hline 1997 & $-52.03 \pm 3.53$ & $1.42 \pm 0.065$ & 64 & 0.88 & $<0.001$ \\
\hline 1998 & $-38.38 \pm 0.23$ & $1.33 \pm 0.045$ & 68 & 0.93 & $<0.001$ \\
\hline \multicolumn{6}{|c|}{ Blackwater } \\
\hline 1997 & $-36.26 \pm 2.69$ & $1.28 \pm 0.050$ & 76 & 0.90 & $<0.001$ \\
\hline 1998 & $-33.54 \pm 2.72$ & $1.25 \pm 0.047$ & 53 & 0.93 & $<0.001$ \\
\hline \multicolumn{6}{|l|}{ Manx } \\
\hline 1997 & $-41.32 \pm 3.17$ & $1.37 \pm 0.053$ & 32 & 0.95 & $<0.001$ \\
\hline 1998 & $-31.82 \pm 2.52$ & $1.14 \pm 0.045$ & 37 & 0.94 & $<0.0001$ \\
\hline
\end{tabular}

ambient temperature and $D^{\circ}$ eff is the number of effective day-degrees between $\mathrm{SL}_{t}$ and $\mathrm{SL}_{0}$. For the $5^{\circ} \mathrm{C}$ group, $G_{\mathrm{o}}$ until $242 D_{\text {eff }}^{\circ}$ was $0.26 \%$ compared with $0.18 \%$ for the $12^{\circ} \mathrm{C}$ group until $222 D^{\circ}$ eff. Therefore, in terms of $D^{\circ}{ }_{\text {eff }}$, fish hatching from eggs incubated at $5^{\circ} \mathrm{C}$ grew more quickly with respect to $\mathrm{BL}$ than fish from $12^{\circ} \mathrm{C}$ eggs (Fig. 7B).

However, differentiation proceeded more rapidly with respect to growth in body length in the $12^{\circ} \mathrm{C}$ than in the $5^{\circ} \mathrm{C}$ group (Fig. 8). For 10 larvae per group of approximately $16 \mathrm{~mm}$ body length, flexion of the notochord was complete in $80 \%$ of the $12^{\circ} \mathrm{C}$ fish but in none of the $5^{\circ} \mathrm{C}$ fish (Fig. 8A,B). In larvae of this body length the actinotrichia in the caudal fin and the development of the deep ventral flexor (DVT) muscle were also more advanced in the $12^{\circ} \mathrm{C}$ than the $5^{\circ} \mathrm{C}$ group (Fig. 8A,B). The $12^{\circ} \mathrm{C}$ larva of $16.2 \mathrm{~mm}$ illustrated in Fig. 8B had a total of 8 anal fin ray muscles showing AchE staining compared to none in the $5^{\circ} \mathrm{C}$ larva of the same length
(Fig. 8A). Flexion of the notochord was not complete until $18 \mathrm{~mm}$ in the larvae hatching from $5^{\circ} \mathrm{C}$ eggs. The development of the deep ventral flexor (DVT) and hypochordal longitudinal muscles (HLM) are shown in Fig. 8C,D. The development of the DVF and HLM muscles in an $18.3 \mathrm{~mm}$ larva at $5^{\circ} \mathrm{C}$ was only slightly more advanced than that in a $14.9 \mathrm{~mm}$ larva at $12^{\circ} \mathrm{C}$ (Fig. $\left.8 \mathrm{C}, \mathrm{D}\right)$. The number of dorsal fin ray muscles with AchE staining is illustrated in Fig. 9A. An ANCOVA revealed a sig-

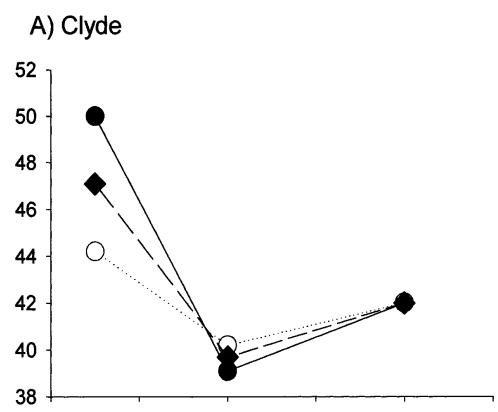

\section{B) Blackwater}
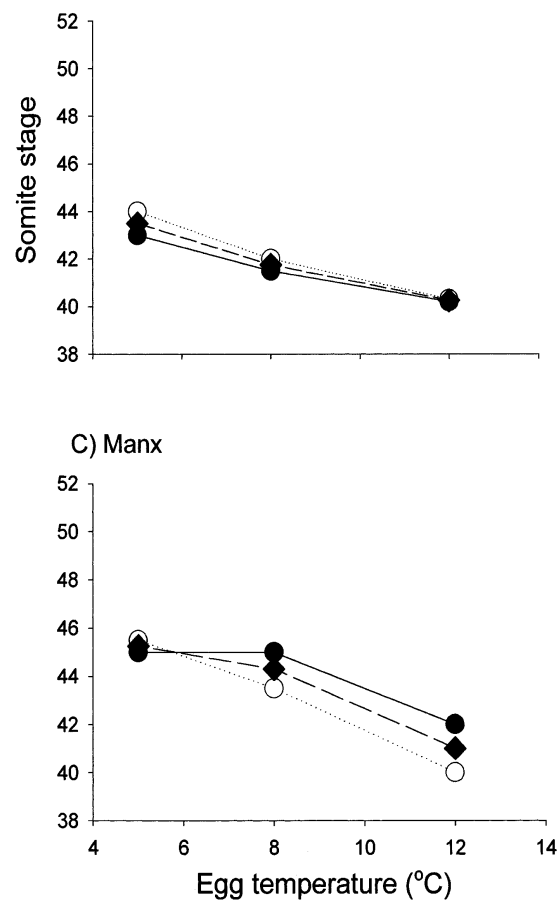

Fig. 4. Clupea harengus. Myofibril formation at different temperatures in embryos of Atlantic herring. The somite stage at which the 20 most rostral somites had myofibrils is illustrated. Values for (A) the Clyde, (B) the Blackwater and (C) the Manx populations were calculated from the regression equations presented in Table 1. Data are presented for the 1997 (๑) and 1998 (O) spawning seasons and the average between years ( $\bullet$ ) 
Table 2. Clupea harengus. Multiple regression analysis of myofibril formation in embryos of Atlantic herring. Results for the final model were based on the backward elimination of explanatory variables (see text for details)

\begin{tabular}{|lcccc|}
\hline Variables & df & $\begin{array}{c}\text { Residual sums } \\
\text { of squares }\end{array}$ & $F$ & p-value \\
\hline Somite & 1048 & 183045.8 & 8732.11 & 0.0001 \\
Egg dry mass & 1058 & 19759.5 & 2.88 & 0.0345 \\
Population & 1055 & 24970.9 & 35.88 & 0.0001 \\
Temperature & 1055 & 24638.6 & 33.66 & 0.0001 \\
Year & 1050 & 22135.1 & 45.18 & 0.0001 \\
Population $\times$ & 1051 & 22258.4 & 35.53 & 0.0001 \\
temperature & 1050.12 & 0.0001 \\
Year $\times$ & & 21324.6 & 46.12 & \\
temperature & 1049 & 19597.8 & & \\
Error & 1047 & 1950 \\
\hline
\end{tabular}
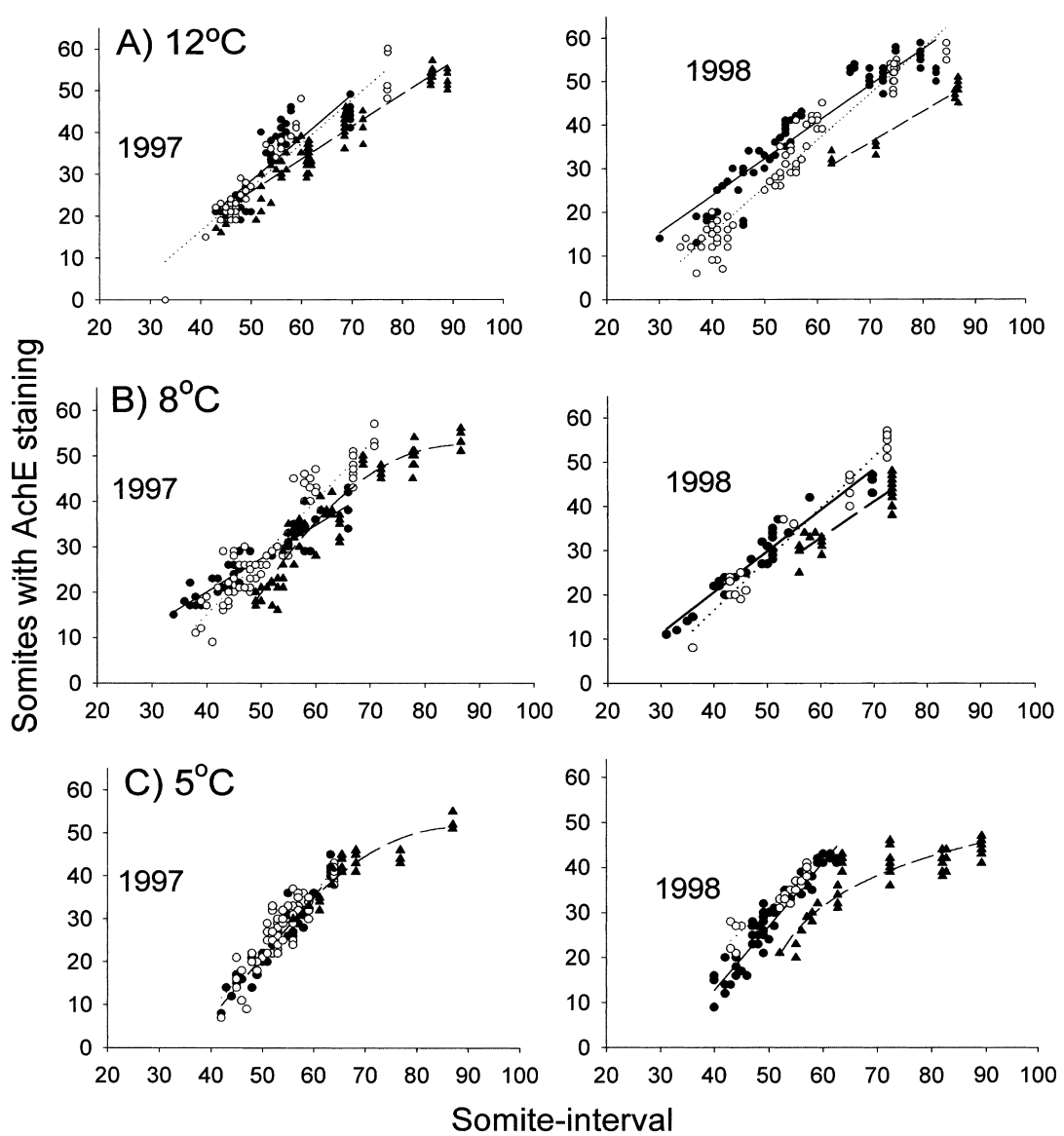

Fig. 5. Clupea harengus. Development of AchE staining at different temperatures in embryos of Atlantic herring. The relationship between the most posterior somite with myofibrils and the somite interval of the embryo is illus-

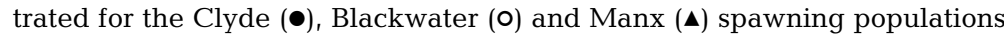
in 1997 and 1998. Each point represents a measurement from an individual embryo. First order linear regressions were fitted to all the data except for the Manx population at $8^{\circ} \mathrm{C}(1997)$ and $5^{\circ} \mathrm{C}$, which were fitted to a second order polynomial. Note that the early samples of Manx herring at $12^{\circ} \mathrm{C}$ were accidently lost for 1998 and so the somite stage at which the 20 most rostral somites had AchE could not be calculated (see Fig. 6)
Table 3. Multiple regression models for different groupings of populations for the response variable myofibrils. $1=$ Clyde, $2=$ Blackwater and $3=$ Manx populations

\begin{tabular}{lcccr}
$\begin{array}{l}\text { Population } \\
\text { grouping }\end{array}$ & df & $\begin{array}{c}\text { Residual sums } \\
\text { of squares }\end{array}$ & $F$ & p-value \\
\hline$[(1,3), 2]$ & 1051 & 23219.4 & 48.37 & 0.0001 \\
{$[1,(2,3)]$} & 1051 & 20538.1 & 12.56 & 0.0001 \\
{$[(1,2), 3]$} & 1051 & 22651.1 & 40.78 & 0.0001 \\
\hline
\end{tabular}

nificant main effect of egg incubation temperature on the number of innervated dorsal fin ray muscles $\left(F_{1,83}=\right.$ 54.83; $\mathrm{p}<0.0001$; covariate body length $F_{1,83}=252.42$; $\mathrm{p}<0.0001)$.

Differences in the development and innervation of the anal fin ray muscles between temperature groups are illustrated in Fig. 10A to F. Typically in the $5^{\circ} \mathrm{C}$ larvae, no fin ray muscles were present by around $16 \mathrm{~mm}$ TL (Fig. 10A), compared with 5 or 6 in the $12^{\circ} \mathrm{C}$ larvae of the same length (Fig. 10B). Neuromuscular junctions staining for AchE activity were observed at both ends of the muscle in the $12^{\circ} \mathrm{C}$ larvae (arrowheads in Fig. 10B). Fig. $10 \mathrm{C}$ shows a $5^{\circ} \mathrm{C}$ larva of $18.1 \mathrm{~mm}$ with 6 innervated anal fin ray muscles compared to 8 in a smaller larva of $16.6 \mathrm{~mm}$ from the $12^{\circ} \mathrm{C}$ group (Fig. 10D). The full complement of innervated fin ray muscles was present in larvae of 21 to $22 \mathrm{~mm}$ total length in both temperature groups (Figs. 10E,F \& 9B). The relationship between larval length and the number of anal fin ray muscles innervated is shown in Fig. 9B. ANCOVA revealed significant main effects of temperature $\left(F_{1,26}=13.16 ; \mathrm{p}<0.001\right)$ over the length range studied (covariate body length $\left.F_{1,26}=26.77 ; \mathrm{p}<0.0001\right)$. It should be noted, however, that with respect to $D_{\text {eff }}^{\circ}$ differentiation proceeded slower in the $12^{\circ} \mathrm{C}$ than the $5^{\circ} \mathrm{C}$ group since the $12^{\circ} \mathrm{C}$ larvae took longer to reach a given SL than the $5^{\circ} \mathrm{C}$ larvae.

\section{Swimming performance}

$U_{\max }$ increased significantly with length for both temperature groups $\left(5^{\circ} \mathrm{C}\right.$ : $-3.12 \mathrm{TL}^{1.92}, \mathrm{r}^{2}=0.42, \mathrm{p}=0.002, F$-statistic; $12^{\circ} \mathrm{C}:-2.20 \mathrm{TL}^{1.21}, \mathrm{r}^{2}=0.48, \mathrm{p}=0.001, F-$ statistic) (Fig. 11). ANCOVA revealed no significant differences in the values of slope exponent $b$ between temperature 
Table 4. Clupea harengus. Relationship between the most posterior somite with AchE staining at the myosepta and somite-interval for embryos of Atlantic herring from different populations. All data were fitted by least squares regression to an equation of the form: number of somites with AchE staining at the myosepta $=a+b$ (somite interval). Values represent mean $\pm \mathrm{SD}$

\begin{tabular}{|c|c|c|c|c|c|}
\hline $\begin{array}{l}\text { Temperature } \\
\left({ }^{\circ} \mathrm{C}\right) / \text { Year }\end{array}$ & $\begin{array}{c}\text { e Intercept } \\
a\end{array}$ & $\begin{array}{l}\text { Slope } \\
b\end{array}$ & df & $\begin{array}{l}\mathrm{r}^{2-} \\
\text { djusted }\end{array}$ & $\mathrm{p}$-value \\
\hline \multicolumn{6}{|l|}{$12^{\circ} \mathrm{C}$} \\
\hline \multicolumn{6}{|l|}{ Clyde } \\
\hline 1997 & $-22.82 \pm 5.18$ & $1.030 \pm 0.095$ & 41 & 0.74 & $<0.0001$ \\
\hline 1998 & $-9.023 \pm 2.12$ & $0.83 \pm 0.035$ & 66 & 0.89 & $<0.0001$ \\
\hline \multicolumn{6}{|l|}{ Blackwater } \\
\hline 1997 & $-24.51 \pm 2.60$ & $1.03 \pm 0.047$ & 45 & 0.91 & $<0.0001$ \\
\hline 1998 & $-27.37 \pm 1.78$ & $1.064 \pm 0.031$ & 73 & 0.94 & $<0.001$ \\
\hline \multicolumn{6}{|l|}{ Manx } \\
\hline 1997 & $-12.85 \pm 1.71$ & $0.77 \pm 0.025$ & 92 & 0.92 & $<0.0001$ \\
\hline \multicolumn{6}{|l|}{$8^{\circ} \mathrm{C}$} \\
\hline \multicolumn{6}{|l|}{ Clyde } \\
\hline 1997 & $-9.28 \pm 2.41$ & $0.73 \pm 0.050$ & 33 & 0.86 & $<0.0001$ \\
\hline 1998 & $-16.49 \pm 2.46$ & $0.93 \pm 0.050$ & 29 & 0.92 & $<0.0001$ \\
\hline \multicolumn{6}{|l|}{ Blackwater } \\
\hline 1997 & $-35.01 \pm 2.62$ & $1.25 \pm 0.048$ & 73 & 0.90 & $<0.0001$ \\
\hline 1998 & $-29.77 \pm 2.99$ & $1.16 \pm 0.053$ & 19 & 0.96 & $<0.0001$ \\
\hline \multicolumn{6}{|l|}{ Manx } \\
\hline 1997 & $-24.26 \pm 3.20$ & $0.96 \pm 0.050$ & 74 & 0.83 & $<0.0001$ \\
\hline 1998 & $-16.48 \pm 4.29$ & $0.82 \pm 0.062$ & 32 & 0.84 & $<0.0001$ \\
\hline \multicolumn{6}{|l|}{$5^{\circ} \mathrm{C}$} \\
\hline \multicolumn{6}{|l|}{ Clyde } \\
\hline 1997 & $-49.60 \pm 3.07$ & $1.42 \pm 0.058$ & 49 & 0.92 & $<0.0001$ \\
\hline 1998 & $-44.07 \pm 2.85$ & $1.42 \pm 0.056$ & 65 & 0.91 & $<0.0001$ \\
\hline \multicolumn{6}{|l|}{ Blackwater } \\
\hline 1997 & $-45.17 \pm 4.031$ & $1.35 \pm 0.073$ & 63 & 0.84 & $<0.0001$ \\
\hline 1998 & $-29.77 \pm 2.99$ & $1.15 \pm 0.052$ & 19 & 0.96 & $<0.0001$ \\
\hline \multicolumn{6}{|l|}{ Manx } \\
\hline 1997 & $-1.55 \pm 5.48$ & $0.63 \pm 0.079$ & 23 & 0.72 & $<0.0001$ \\
\hline 1998 & $-1.05 \pm 4.11$ & $0.51 \pm 0.057$ & 40 & 0.66 & $<0.0001$ \\
\hline
\end{tabular}

groups. However, initial rearing temperature had a significant effect on intercepts a $(\mathrm{p}=0.0007$, ANCOVA). Adjusted mean $U_{\max }$ was $24 \%$ higher in the $12^{\circ} \mathrm{C}$ group than the $5^{\circ} \mathrm{C}$ group (Fig. 11). At $12 \mathrm{~mm}$ when differences in the stiffening elements of the median fins were most pronounced between groups, $U_{\max }$ was $40 \%$ higher in the 12 than $5^{\circ} \mathrm{C}$ fish.

During steady swimming the maximum yaw of the head in larvae of around $13 \mathrm{~mm}$ TL were significantly higher in the $5^{\circ} \mathrm{C}$ group $\left(32.4 \pm 3.8^{\circ}, \mathrm{n}=10\right)$ than in the $12^{\circ} \mathrm{C}$ group $\left(17.9 \pm 2.3^{\circ}, \mathrm{n}=7\right)($ Mean $\pm \mathrm{SEM})(\mathrm{p}=$ 0.006, 1-way ANOVA).

\section{DISCUSSION}

Previous studies with Clyde herring have found that the rostral to caudal progression of myofibril synthesis in both slow and fast myotubes begins at earlier somite
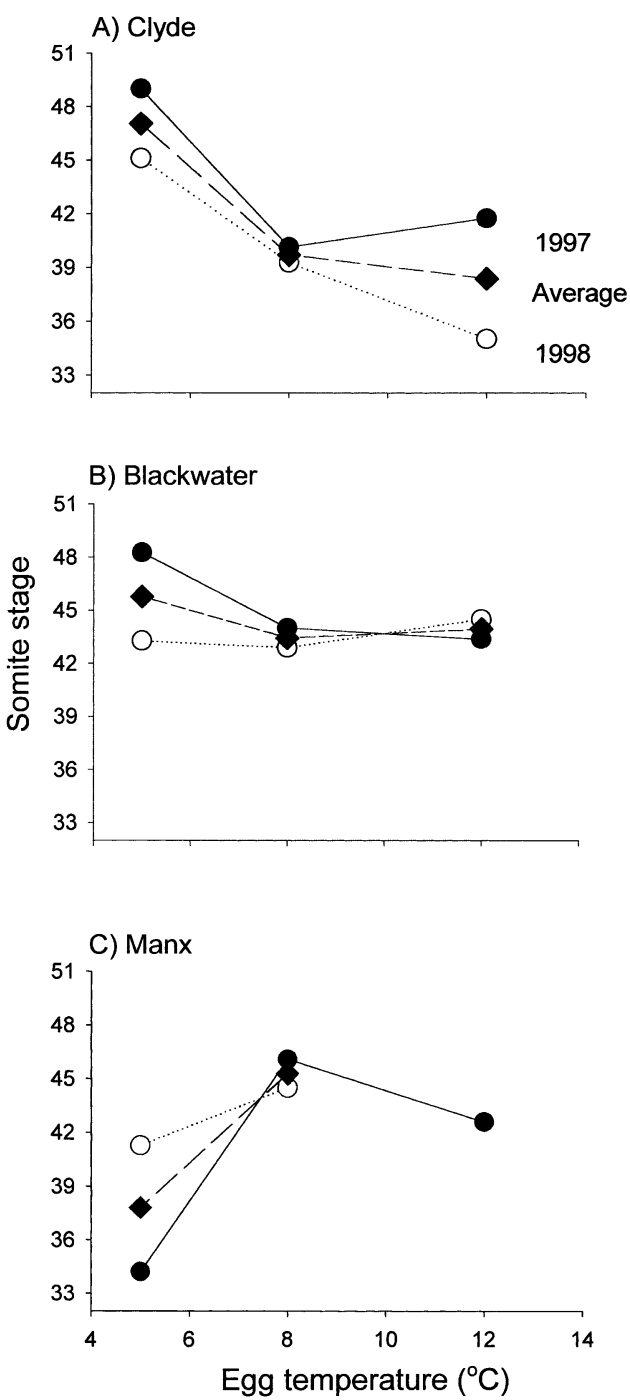

Fig. 6. Clupea harengus. Development of AchE staining at different temperatures in embryos of Atlantic herring. The somite stage at which the 20 most rostral somites had AchE staining is illustrated. Values for (A) the Clyde, (B) the Blackwater and (C) the Manx populations were calculated from the regression equations presented in Table 4 . Data are presented for the $1997(\bullet)$ and 1998 (O) spawning seasons and the average between years (

stages as temperature is increased (Johnston et al. 1995, 1997). For example, in 50-somite stage embryos from the 1995 and 1996 spawning seasons, myofibrils were present in the muscle pioneer fibres of the first 31 somites at $12^{\circ} \mathrm{C}$, but only in the first 20 somites at $5^{\circ} \mathrm{C}$ (Johnston et al. 1997). We obtained similar results for Clyde herring in each of the years studied, suggesting a highly consistent response to temperature by this spawning stock. By the 56-somite stage, the density of myofibrils in the fast fibres of rostral somites was found 
Table 5. Clupea harengus. Multiple regression analysis of acetylcholinesterase staining in embryos of Atlantic herring. Results for the final model were based on the backward elimination of explanatory variables (see text for details)

\begin{tabular}{|lrrrr|}
\hline Variables & df & $\begin{array}{c}\text { Residual sums } \\
\text { of squares }\end{array}$ & $F$ & p-value \\
\hline Somite & 1299 & 185572.5 & 9177.48 & 0.0001 \\
Egg dry mass & 1301 & 23704.6 & 13.37 & 0.0001 \\
$\begin{array}{l}\text { Population } \\
\text { Temperature }\end{array}$ & 1312 & 37682.4 & 59.23 & 0.0001 \\
$\begin{array}{l}\text { Year } \\
\begin{array}{l}\text { Population } \times \\
\text { temperature }\end{array}\end{array}$ & 1310 & 29224.9 & 29.31 & 0.0001 \\
$\begin{array}{l}\text { Population } \times \\
\text { year }\end{array}$ & 1307 & 26510.8 & 22.06 & 0.0001 \\
$\begin{array}{l}\text { Year } \times \\
\text { temperature }\end{array}$ & 1304 & 26835.9 & 27.11 & 0.0001 \\
$\begin{array}{l}\text { Population } \times \\
\text { year } \times \text { temperature }\end{array}$ & 1300 & 24008.7 & 14.32 & 0.0001 \\
$\begin{array}{l}\text { Egg dry mass } \times \\
\text { population }\end{array}$ & 1298 & 23658.4 & 18.75 & 0.0001 \\
Error & & 22994.0 & & 0.0001 \\
\hline
\end{tabular}

to be significantly greater at 15 than $5^{\circ} \mathrm{C}$ (Johnston et al. 1997). However, by hatch, the volume density of myofibrils in the fast muscle fibres of Clyde herring was relatively independent of temperature (Vieira \& Johnston 1992).

Temperature also affected the timing of development of motor innervation in Clyde herring embryos (Figs. 5 \& 6). In particular, AchE staining at the neuromuscular junctions of the axial muscle fibres appeared later with respect to somite intervals at 5 than $8^{\circ} \mathrm{C}$ (Fig. 6), as was reported previously for the 1995 and 1996 spawning seasons (Johnston et al. 1997). On the basis of the genetic homogeneity reported for herring stocks (Ryman et al. 1984, Turan et al. 1998), we tested the hypothesis that a similar plasticity of neuromuscular development would be observed in other spawning populations. Multiple regression analysis and backward elimination of response variables indicated significant effects of pop, temp, egg and year on the development of myofibrils and AchE activity. Multiple regression with groups of populations indicated that Clyde herring accounted for most of the differences in

Table 6. Multiple regression models for different groupings of populations for the response variable AchE staining. $1=$ Clyde, 2 = Blackwater and 3 = Manx populations

\begin{tabular}{|lcccc|}
\hline $\begin{array}{l}\text { Population } \\
\text { grouping }\end{array}$ & df & $\begin{array}{c}\text { Residual sums } \\
\text { of squares }\end{array}$ & $F$ & p-value \\
\hline$[(1,3), 2]$ & 1305 & 39530.2 & 93.03 & 0.0001 \\
{$[1,(2,3)]$} & 1305 & 27122.5 & 33.29 & 0.0001 \\
{$[(1,2), 3]$} & 1305 & 28345.5 & 43.16 & 0.0001 \\
\hline
\end{tabular}
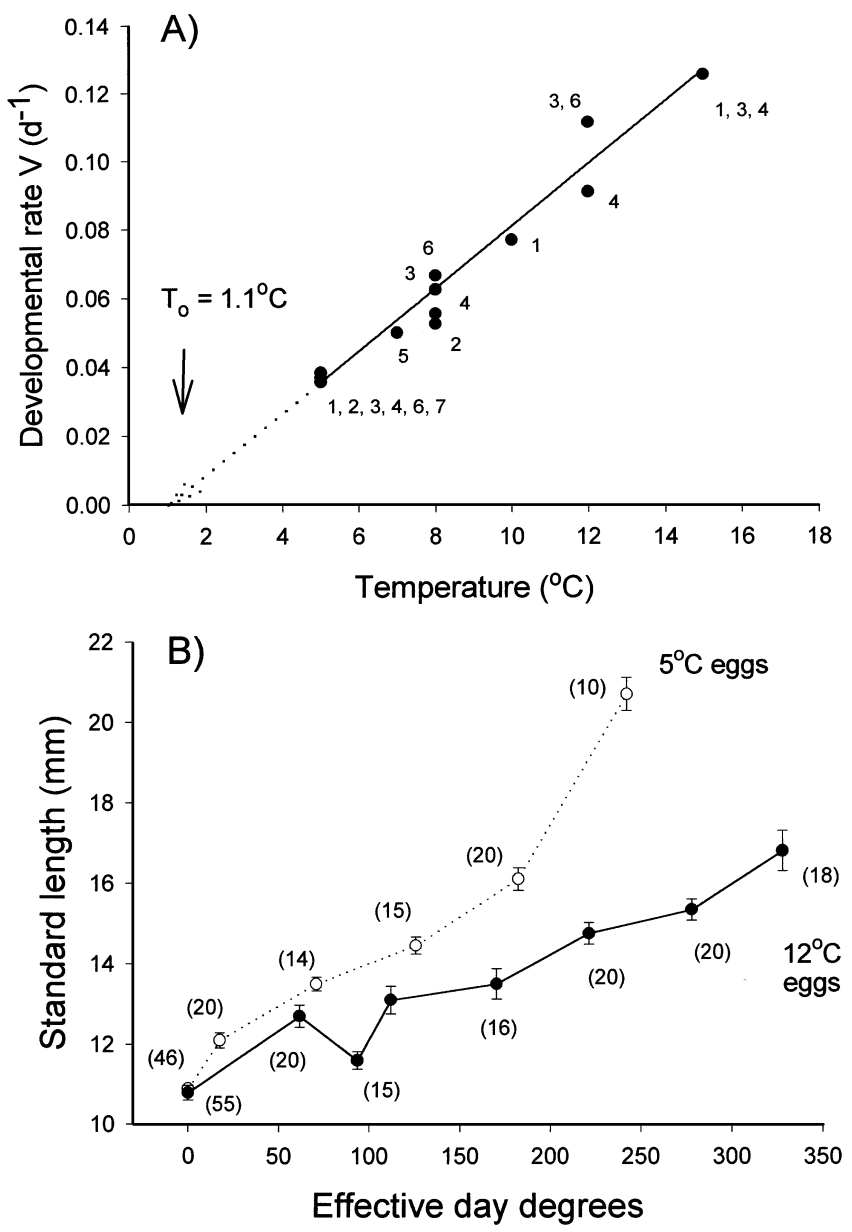

Fig. 7. Clupea harengus. (A) Development rate $V\left(\mathrm{~d}^{-1}\right.$ to $50 \%$ hatching) in Clyde herring embryos as a function of temperature. The line was calculated by linear regression $V=-0.0098$ $( \pm 0.0036)+0.0091( \pm 0.0004) \times T^{\circ} \mathrm{C}\left(\right.$ Adj r ${ }^{2}=0.97, \mathrm{n}=18 ; \mathrm{p}<$ $0.0001)$ (mean $\pm \mathrm{SE}$ ). The sources of data were as follows: (1) Vieira \& Johnston (1992), (2) Johnston (1993), (3) Johnston et al. (1995), (4) Johnston et al. (1997), (5) Yin \& Craik (1992); (6) present study 1997 spawning season; and (7) present study 1998 spawning season. (B) Growth of Clyde herring larvae reared at either $5(\mathrm{O})$ or $12^{\circ} \mathrm{C}(\bullet)$ until first feeding and then transferred to the ambient temperature regime shown in Fig. 1. The standard length of larvae $(\mathrm{mm})$ was plotted against the accumulative effective day degrees of development $\left(D_{\text {eff }}^{\circ}\right)$ (see text for details). Values represent mean \pm SE. The number of larvae sampled is shown in brackets

the final model selected (Tables $3 \& 6$ ). Although the formation of myofibrils was delayed with respect to somite stage at $5^{\circ} \mathrm{C}$ compared to $12^{\circ} \mathrm{C}$ in the Blackwater and Manx populations, the effect was much less pronounced than for Clyde herring (Fig. 4). Furthermore, the development of AchE staining at the myosepta occurred at a similar somite-stage at all temperatures in the Blackwater and Manx populations, in marked contrast to the results for Clyde her- 


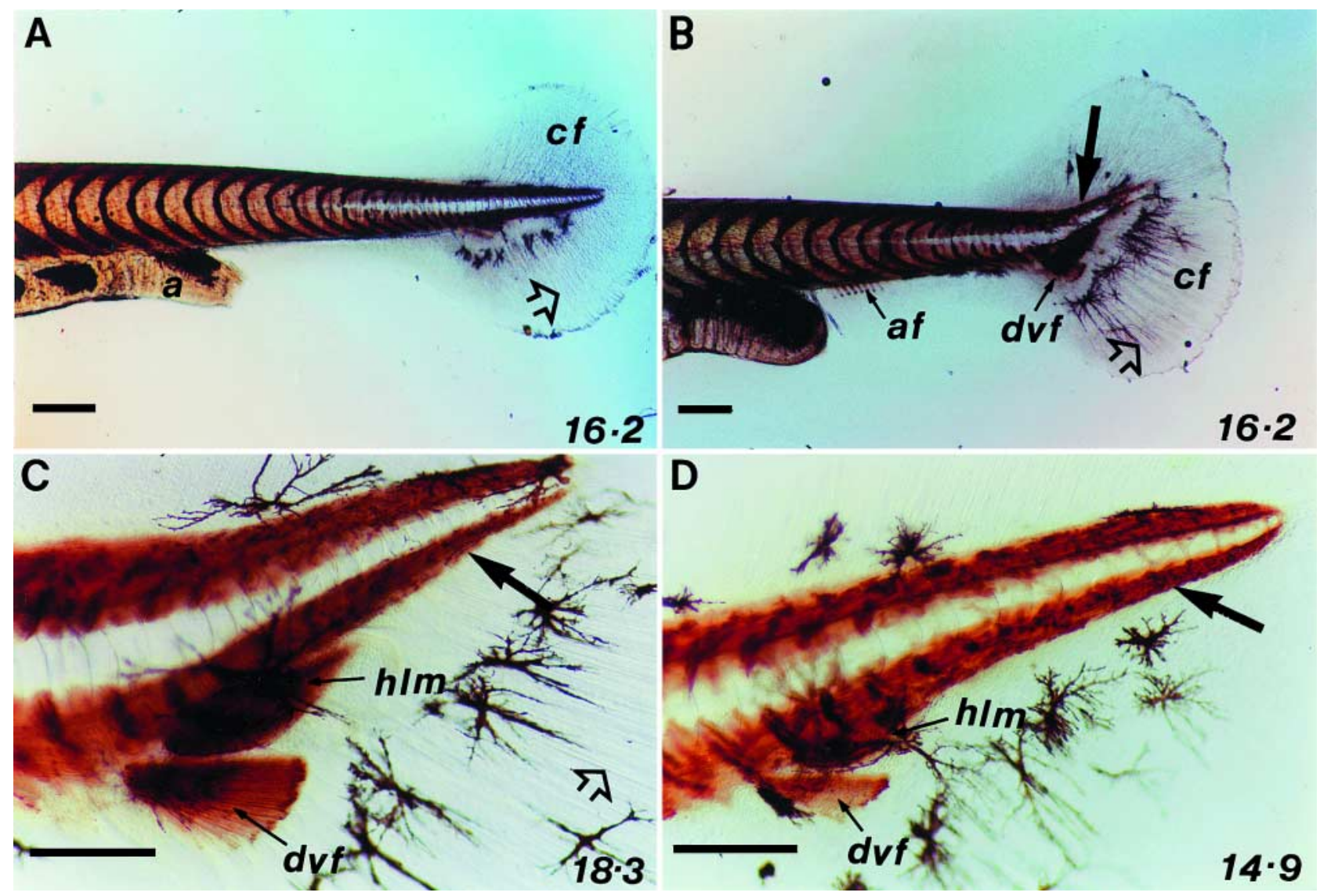

Fig. 8. Whole mount Clyde herring larvae stained for AchE activity. $(\mathrm{A}, \mathrm{C})$ larvae reared at $5^{\circ} \mathrm{C}$ until first feeding and (B,D) larvae reared at $12^{\circ} \mathrm{C}$ until first feeding. All groups of larvae were subsequently reared at ambient seawater temperature (see Fig. 1). The total body length of the larvae is shown in the bottom right-hand corner of each panel. Flexion of the notochord is indicated by an arrow. The open arrowhead shows the actiotrichia strengthening the larval caudal fin. Abbreviations: a: anus; af: anal fin ray muscle; cf: caudal fin; dvf: deep ventral flexor muscle; hlm: hypochordal longitudinal muscle. Scale bars $=200 \mu \mathrm{m}$
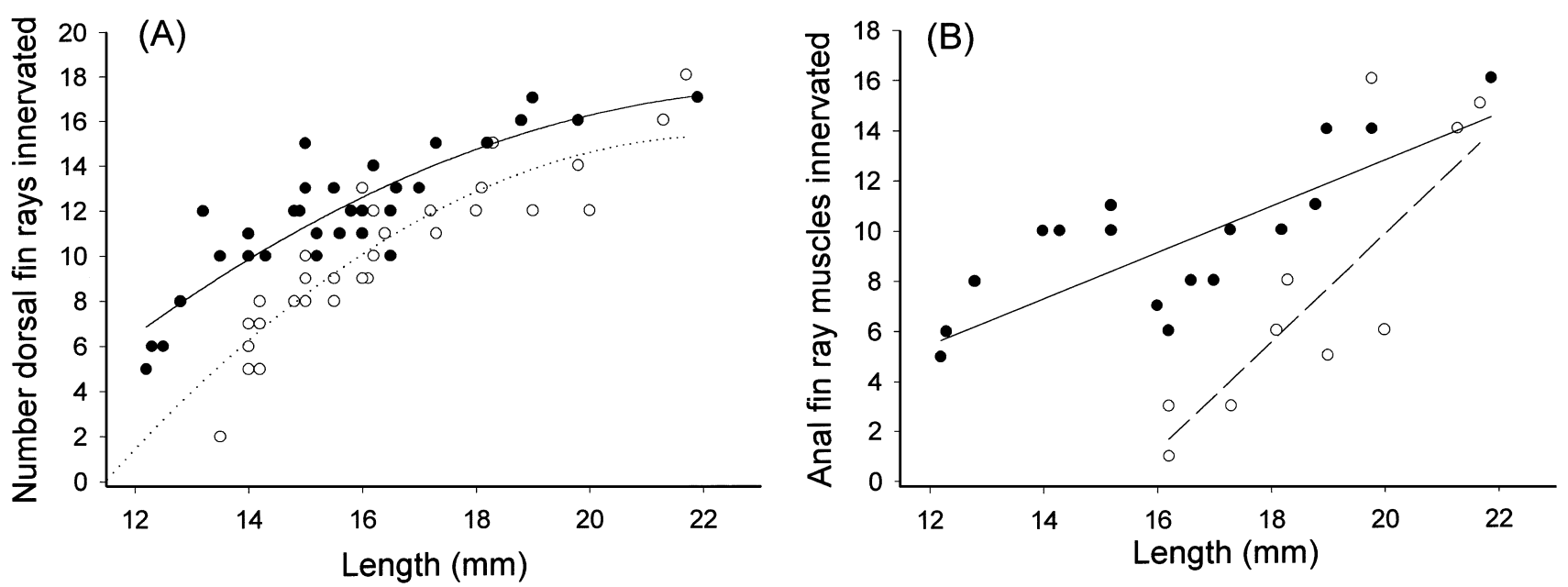

Fig. 9. Number of (A) dorsal fin ray muscles and (B) anal fin ray muscles innervated in relation to total body length for Clyde herring larvae reared under the 2 thermal regimes illustrated in Fig. 1. Fish initially reared at 5 (o) and $12^{\circ} \mathrm{C}(\bullet)$ until first feeding and then transferred to ambient seawater temperature. A second order polynomial was fitted to the data in (A) of the form: $\mathrm{f}=y 0+a^{*} x+b^{*} x^{2}$. For the $5^{\circ} \mathrm{C}$ fish $y 0=-49.73 \pm 14.73, a=5.77 \pm 1.73, b=-0.13 \pm 0.050 ;$ Adjusted ${ }^{2}=0.79 ;$ ANOVA $F_{2,40}=$ $70.21 ; \mathrm{p}<0.0001$. For the $12^{\circ} \mathrm{C}$ fish, $y 0=-26.65 \pm 9.34, a=3.69 \pm 1.14, b=-0.077 \pm 0.034 ;$ Adjusted ${ }^{2}=0.75 ;$ ANOVA $F_{2,36}=57.65$; $\mathrm{p}<0.0001$. A linear regression equation was fitted to the data in (B) of the form: $\mathrm{f}=y 0+a^{*} x$. For the $5^{\circ} \mathrm{C}$, fish $y 0=-32.90 \pm 8.76$ and $a=2.13 \pm 0.47 ;$ Adjusted $\mathrm{r}^{2}=0.62 ;$ ANOVA $F_{1,11}=20.96 ; \mathrm{p}<0.0008$. For the $12^{\circ} \mathrm{C}$ fish, $y 0=-5.42 \pm 3.13$ and $a=0.91 \pm 0.19$; 

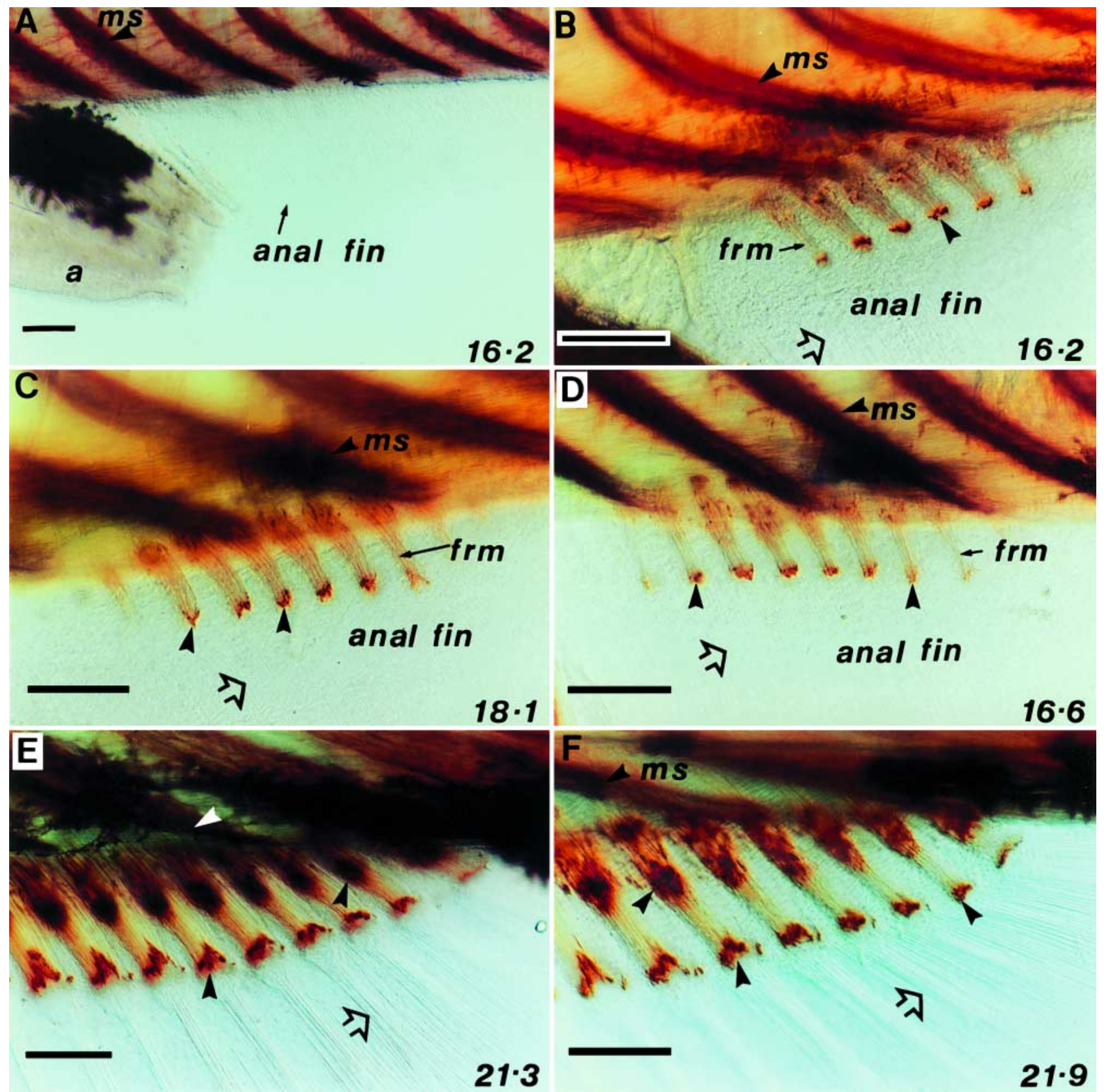

Fig. 10. Development of innervation to the anal fin ray muscles in Clyde herring. Whole mount larvae were stained for acetylcholinesterase (AchE) activity and photographed using DIC optics. (A,C,E) larvae reared at $5^{\circ} \mathrm{C}$ until first feeding and $(\mathrm{B}, \mathrm{D}, \mathrm{F})$ larvae reared at $12^{\circ} \mathrm{C}$ until first feeding. All groups of larvae were reared at ambient seawater temperature following first feeding (see Fig. 1). The total body length of the larvae is shown in the bottom right-hand corner of each panel. The arrowheads illustrate muscle endplates stained for AchE activity. Open arrowheads illustrate actiotrichia strengthening the anal fin. Abbreviations: a: anus; frm: fin ray muscle; ms: myosepta. Scale bars $=200 \mu \mathrm{m}$

ring (Fig. 6). Thus, the data obtained did not support our original hypothesis of a similar developmental response to temperature in the different spawning stocks.

Egg dry mass is known to differ between herring spawning populations, with larger eggs producing longer larvae (Blaxter \& Hempel 1963). The relative importance of parental genotype and maternal environmental effects in determining egg size in herring is unknown (Morley et al. 1999). Egg dry mass was a significant covariate for the development of myofibrils and AchE staining in our model. However, egg dry 


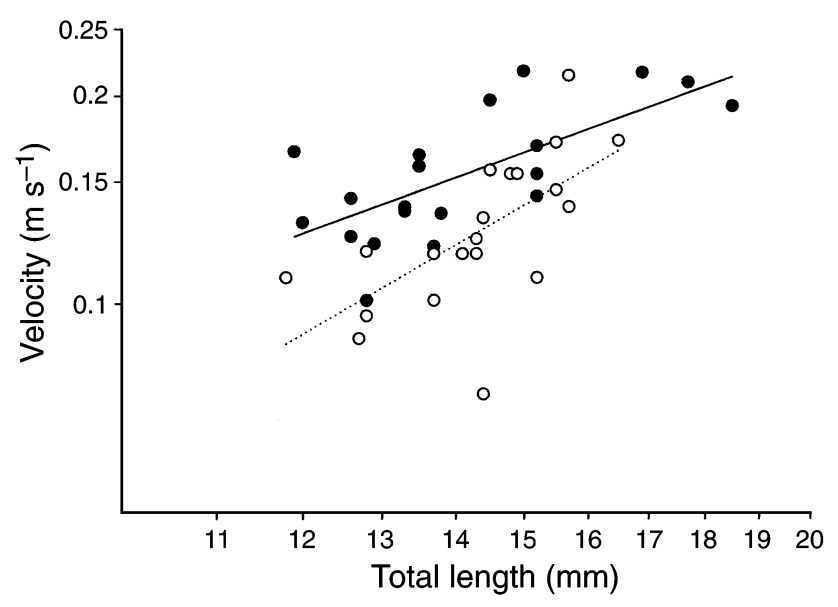

Fig. 11. Maximum velocity attained during escape responses in Clyde herring larvae. Larvae were reared at $5^{\circ} \mathrm{C}(\mathrm{O}, \cdots \cdots . .$. and at $12^{\circ} \mathrm{C}(\bullet, \longrightarrow)$ until first feeding when they were transferred to ambient seawater temperatures. First order linear regressions were fitted to the data

mass cannot explain the observed population differences since average values for the families studied were not significantly different.

There is a variety of evidence to suggest that genotype-temperature interactions are responsible for a substantial amount of variation in developmental characteristics (Mitton \& Koehn 1976, Beacham 1988). Mitton \& Koehn (1976) reared Fundulus heteroclitus (Cyprinodontidae) from the north of Long Island on the Atlantic seaboard of the United States at ambient temperatures and in heated water to determine patterns of variation in the morphology of offspring. Fish living in heated water exhibited a marked divergence in morphology from control fish and a convergence with wild populations living at more southerly latitudes. It was suggested that greater morphological variation in the heated water group was associated with a combination of a breakdown in developmental homeostasis and the selection of rare phenotypes within the population (Mitton \& Koehn 1976).

During the early larval stages of herring there are dramatic changes in body shape, fin development and style of swimming (Batty 1984). When the larvae hatch at around $8 \mathrm{~mm}$ the body is circular in cross-section and a large primordial fin extends along the dorsal and ventral margins of the trunk. At this stage the larvae utilise an anguilliform mode of swimming in which the amplitude of body movements increases linearly along the body (Batty 1984). The primordial fin is gradually absorbed as the dorsal, anal and caudal fins start to develop and has disappeared by the end of notochord flexion (Batty 1984). Concomitant with these changes in body morphology, which are complete by around $22 \mathrm{~mm}$, there is a gradual transition from an anguilli- form to a sub-carangiform style of swimming in which the amplitude of body movements is less at the head but increases markedly towards the tail, and inertial forces dominate (Batty 1984). As carangiform swimming becomes more important, the trunk becomes laterally compressed and the caudal fin acts as a flexible paddle transferring the power provided by the muscles to the water (Batty 1984).

A remarkable finding in the present study was that variations in incubation temperature alone influenced the developmental programme for the median fins and associated musculoskeletal elements in larvae. Thus, the development of the tail fin and associated musculature occurred at shorter body lengths in larvae from eggs incubated at 12 than $5^{\circ} \mathrm{C}$ (Fig. 8A,C,D). Egg incubation temperature also influenced the body length at which the dorsal and anal fin ray muscles developed and became innervated (Figs. 9 \& 13). The flexible segmented fin rays and associated muscles of teleosts play an important role in adjusting the stiffness and camber of the fins during locomotion and hence the transfer of the propulsive power generated by the muscles to the water (Videler 1993, Plaut 2000). We found evidence that the morphological differences between the 5 and $12^{\circ} \mathrm{C}$ groups of larvae were reflected in the body length at which the transition from an anguilliform to a sub-carangiform style of swimming occurred. Differences in the development of the median fins and associated musculature were also associated with changes in fast-start performance, such that larvae between 11 to $15 \mathrm{~mm}$ TL that were initially reared at $12^{\circ} \mathrm{C}$ had greater maximum velocities than larvae of the same length range reared at $5^{\circ} \mathrm{C}$.

Our results indicate an uncoupling between the effects of temperature on growth and tissue differentiation. Similarly, previous studies with fish have shown that within the natural thermal range of a species an increase in rearing temperature usually accelerates growth and development and shortens the time for larvae to complete metamorphosis. For example, in Japanese flounder Paralichthys olivaceus the final stage of metamorphosis was completed at significantly shorter body lengths at 19 rather than $13^{\circ} \mathrm{C}$ (Seikai et al. 1986), consistent with a differential effect of temperature on growth and tissue differentiation. Similarly, the appearance of teeth in red drum Sciannops ocellatus larvae was accelerated by $25 \%$ in terms of TL at $26.5^{\circ} \mathrm{C}$ compared to $22.5^{\circ} \mathrm{C}$, although other characteristics were less affected (Fuiman et al. 1998). The use of effective degree days to normalise growth at different temperatures remains controversial (Fuiman et al. 1998). Developmental effects on growth phenotype, such as those found in the present study, make it particularly difficult to gauge the effectiveness of such normalisations. 
How important is the maximum swimming speed of herring larvae for determining the outcome of predator attacks? Fuiman \& Batty (1994) investigated the susceptibility of Clyde herring to predation by juvenile cod and herring. They found that between 14 and $24 \mathrm{~mm}$ TL predator errors rather than the evasive responses of the larvae determined predator-prey outcomes, probably due to the low levels of responsiveness of the prey. Larvae greater than $25 \mathrm{~mm}$ TL were more likely to respond to predator attacks and escape attempts increased in effectiveness (Fuiman 1989), reflecting the increasing sophistication of the sensory systems and the filling of the otic bullae with gas (Blaxter 1988). Blaxter (1988) has suggested that herring larvae less than $25 \mathrm{~mm}$ TL probably rely on their transparency to avoid encounters with predators and reduce their apparent target size. Thus, although the maximum length-specific swimming velocity of the $12^{\circ} \mathrm{C}$ larvae was superior to that of the $5^{\circ} \mathrm{C}$ group, this may be of little significance in terms of avoiding predation. However, the strike behaviour and velocity of herring larvae during feeding was found to be modified by rearing temperature (Morley \& Batty 1996), and perhaps by the mechanism(s) outlined in the present study.

In conclusion, our results showed that the thermal regime experienced by the eggs was a significant source of phenotypic variation in larval herring, although the response to temperature varied between different spawning populations. In the Clyde population the thermal regime to first feeding continued to exert an influence on the developmental programme of the median fins and associated musculature until $18.5 \mathrm{~mm}$ TL, with significant consequences for swimming style and performance. The hypothesis that such developmental plasticity influences feeding success requires future investigation.

Acknowledgements. This work was supported by a grant from the Developmental Ecology of Marine Animals (DEMA) thematic programme funded by the Natural Environment Research Council, UK. We are grateful to Dr Bob Batty and staff at the NERC Dunstaffnage Marine Laboratory for larval rearing. We also wish to thank Marguerite Abercromby and Jim Killeen for help with embryonic sampling and Dr Marti McCracken (Mathematical Institute, University of St Andrews) for assistance with the statistical analysis.

\section{LITERATURE CITED}

Anokhina L (1971) Maturation of Baltic and White Sea herring with special reference to variations in fecundity and egg diameter. Rapp Cons Explor Mer 160:12-17

Batty RS (1984) Development of swimming movements and musculature of larval herring (Clupea harengus). J Exp Biol 110:217-229

Beacham TD (1988) A genetic analysis of early development in pink (Oncorhynchus gorbuscha) and chum samon (Oncorhynchus keta) at three different temperatures. Genome 30:89-96

Blaxter JHS (1988) Pattern and variety in development. In: Hoar WS, Randall DJ (eds) Fish physiology, Vol XI. The physiology of developing fish, Part A. Eggs and larvae. Academic Press, New York, p 1-58

Blaxter JHS, Hempel G (1963) The influence of egg size on herring larvae (Clupea harengus). J Cons Int Explor Mer 28:210-240

Bowers AB (1969) Spawning beds of Manx autumn herring. J Fish Biol 1:355-359

Dahle G, Eriksen AG (1990) Spring and autumn spawners of herring (Clupea harengus) in the North Sea, Skagerrak; population genetic analysis. Fish Res 9:131-141

Fuiman LA (1989) Vulnerability of Atlantic herring larvae to predation by yearling herring. Mar Ecol Prog Ser 51: 291-299

Fuiman LA, Batty RS (1994) Susceptibility of Atlantic herring and plaice larvae to predation by juvenile cod and herring at two constant temperatures. J Fish Biol 44:23-34

Fuiman LA, Poling KR, Higgs DM (1998) Quantifying developmental progress for comparative studies of larval fishes. Copeia (3):602-611

Grant WS (1984) Biochemical population genetics of Atlantic herring, Clupea harengus. Copeia, Report no. 2 Rit Fiskideildar 1:1-54

Greer-Walker MG, Bird AC, Pull GA (1972) The total number of white skeletal muscle fibres in cross-section as a character for stock separation in North Sea herring (Clupea harengus). J Cons Int Explor Mer 34:238-243

Halpern ME, Ho RK, Walker C, Kimmel CB (1993) Induction of muscle pioneers and floor plate is distinguished by the zebrafish no tail mutation. Cell 75:99-111

Hempel G, Blaxter JHS (1961) The experimental modification of meristic characters in herring (Clupea harengus L.). J Cons Int Explor Mer 3:336-346

Hill J, Johnston IA (1997a) Photomicrographic atlas of herring embryonic development. J Fish Biol 51:960-977

Hill J, Johnston IA (1997b) Temperature and neural development of the Atlantic herring (Clupea harengus L.) Comp Biochem Physiol 117A:457-462

Johnston IA (1993) Temperature influences muscle differentiation and the relative timing of organogenesis in herring (Clupea harengus) larvae. Mar Biol 116:363-379

Johnston IA (1999) Muscle development and growth: potential implications for flesh quality in fish. Aquaculture 177: 99-115

Johnston IA, Vieira VLA, Abercromby M (1995) Temperature and myogenesis in embryos of the Atlantic herring Clupea harengus. J Exp Biol 198:1389-1403

Johnston IA, Vieira VLA, Hill J (1996) Temperature and ontogeny in ectotherms: muscle phenotype in fish. In: Johnston IA, Bennett AF (eds) Animals and temperature phenotypic and evolutionary adaptation. Soc Exp Biol Seminar Ser, Vol 59. University of Cambridge Press, Cambridge, p 151-181

Johnston IA, Cole NJ, Vieira VLA, Davidson I (1997) Temperature and developmental plasticity of muscle phenotype in herring larvae. J Exp Biol 200:849-868

Johnston IA, Cole NJ, Abercromby M, Vieira VLA (1998) Embryonic temperature modulates muscle growth characteristics in larval and juvenile herring. J Exp Biol 201: 623-646

Jones SR, Jeffs TM (1991) Near-surface sea temperatures in coastal waters of the North Sea, English Channel and Irish Sea. Data Report no 24. Ministry of Agriculture Fisheries \& 
Food Research: Her Majesty's Stationery Office

Jørstad KE, Nævdal G (1981) Significance of population genetics on the management of herring stocks. Cons Int Explor Mer 1981/H 64

Jørstad KE, Dahle G, Paulsen OI (1994) Genetic comparison between Pacific herring (Clupea pallasi) and a Norwegian fjord stock of Atlantic herring (Clupea harengus). Can J Fish Aquat Sci 51(Suppl 1):233-239

Karnovsky MJ, Roots L (1964) A direct colouring thiocholine method for cholinesterases. J Histochem Cytochem 12: $219-221$

Koumans JTM, Akster HA (1995) Myogenic cells in development and growth of fish. Comp Biochem Physiol 110A: $3-20$

Krzanowski WJ (1998) An introduction to statistical modelling. Arnold, London

Mitton JB, Koehn RK (1976) Morphological adaptation to thermal stress in a marine fish, Fundulus heteroclitus. Biol Bull 151:548-549

Morley S, Batty RS (1996) The effects of temperature on 'S-strike' feeding of larval herring, Clupea harengus L. Mar Freshw Behav Physiol 28:123-136

Morley SA, Batty RS, Geeffen AJ, Tyler P (1999) Egg size manipulation: a technique for investigating maternal effects on the hatching characteristics of herring. J Fish Biol 55(Suppl A):233-238

Parrish BB, Saville A (1967) Changes in the fisheries of North Sea and Atlanto-Scandian herring stocks and their causes. Oceanogr Mar Biol Annu Rev 5:409-447

Plaut I (2000) Effect of fin size on swimming performance, swimming behaviour and routine activity of zebrafish Danio rerio. J Exp Biol 203:813-820

Rosenberg R, Palmén LE (1982) Composition of herring stocks in the Skagerrak-Kattegat and the relations of these stocks with those of the North Sea and adjacent waters. Fish Res $1: 83-104$

Editorial responsibility: Roger Hughes (Contributing Editor), Bangor, Wales, UK
Ryman NU, Lagercrantz L, Andersson R, Chakraborty R, Rosenberg R (1984) Lack of correspondence between genetic and morphological variability patterns in Atlantic herring (Clupea harengus). J Hered 53:687-704

Seikai T, Tanangonan JB, Tanaka M (1986) Temperature influence on larval growth and metamorphosis of the Japanese flounder Plalalichthys olivaceus in the laboratory. Bull Jpn Soc Sci Fish 52:977-982

Temple GK, Fox CJ, Stewart R, Johnston IA (2000) Variability in muscle growth characteristics during the spawning season in a natural population of Atlantic herring (Clupea harengus L.). Mar Ecol Prog Ser 205:271-281

Turan C, Carvalho GR, Mork J (1998) Molecular genetic analysis of Atlanto-Scandian herring (Clupea harengus) populations using allozymes and mitochondrial DNA markers. J Mar Biol Assoc UK 78:269-283

Videler JJ (1993) Fish swimming. Chapman \& Hall, London

Vieira VLA, Johnston IA (1992) Influence of temperature on muscle-fibre development in larvae of the herring Clupea harengus. Mar Biol 112:333-341

Wakeling JM, Johnston IA (1998) Muscle power output limits fast-start performance in fish. J Exp Biol 201:1505-1526

Weisberg S (1985) Applied linear regression. John Wiley, New York

Weltzien FA, Planas M, Fyhn HJ (1999) Temperature dependency of early growth of turbot (Scophthalmus maximus L.) and its implication for developmental progress. J Exp Mar Biol Ecol 242:201-210

Wheeler JP, Winters GH (1984) Homing of Atlantic herring in Newfoundland waters as indicated by tagging data. Can J Fish Aquat Sci 41:108-117

Yin M, Craik JCA (1992) Biochemical changes during development of eggs and yolk-sac larvae of herring and plaice. Chin J Oceanol Limnol 10:347-358

Zar JH (1996) Biostatistical analysis. Prentice-Hall International, London

Submitted: June 28, 2000; Accepted: July 4, 2000

Proofs received from author(s): March 8, 2001 